\title{
Herbal Medicines in the Treatment of Dyspepsia: An Overview
}

\author{
Authors \\ Affiliations \\ 1 Pharmaceutical Sciences Graduate Program, University of \\ Vale do Itajaí, Itajaí, Brazil. \\ 2 Laboratory of Cardiovascular Pharmacology (LaFac), \\ Faculty of Health Sciences, Federal University of Grande \\ Dourados (UFGD), Dourados, MS, Brazil \\ Key words \\ antiulcer, gastroprotective, Helicobacter pylori, medicinal \\ plants, natural products, prokinetic \\ received \\ February 8, 2021 \\ accepted after revision \\ August 3, 2021 \\ published online \\ September 2, 2021 \\ Bibliography \\ Planta Med 2022; 88: 664-677 \\ DOI $\quad 10.1055 / a-1580-7782$ \\ ISSN 0032-0943 \\ (c) 2021. Thieme. All rights reserved. \\ Georg Thieme Verlag KG, Rüdigerstraße 14, \\ 70469 Stuttgart, Germany \\ Correspondence \\ Dr. Arquimedes Gasparotto Junior \\ Laboratory of Cardiovascular Pharmacology (LaFaC), Faculty \\ of Health Sciences, Federal University of Grande Dourados \\ Rodovia Dourados-Itahum, km 12, P. O. Box 533 \\ 79804-970 Dourados, MS, Brazil \\ Phone: + 55(67) 34102333, Fax: + 55(67)34102321 \\ arquimedesjunior@ufgd.edu.br
}

Thaise Boeing ${ }^{1}$, Priscila de Souza ${ }^{1 \mathbb{D}}$, Luisa Mota da Silva ${ }^{1}$, Arquimedes Gasparotto Junior ${ }^{2 \mathbb{D}}$
Supplementary material is available under
https://doi.org/10.1055/a-1580-7782

\section{ABSTRACT}

This review focuses on the efficacy of herbal medicines for managing dyspepsia in humans and animals. Searches were conducted on the PubMed, Science Direct, and Medline databases, for publications in the last 3 years. In each database, the search terms used consisted of the 2 key terms describing the disorder and subtypes plus each of the terms relating to the therapy. The key terms used were "natural product" and "medicinal plant" in a cross-over with "dyspepsia" and "functional dyspepsia” (i.e., gastroprotection, Helicobacter pylori infection, prokinetic). We included all human and animal studies on the effects of herbal medicines reporting the key outcome of dyspepsia symptoms. Preclinical studies using critically validated models showed that most medicinal plants with gastroprotective action had antioxidant, anti-inflammatory, anti-apoptotic, and antisecretory effects. Moreover, several species displayed anti Helicobacter pylori and prokinetic efficacy. The data availability of controlled clinical studies is currently minimal. The use of different methodologies and the minimal number of patients raise doubts about the effects of these preparations. Only adequate clinical trials with scientifically validated methods can determine whether different herbal medicines can be used as viable alternatives to the conventional pharmacological treatments used to control dyspepsia symptoms.

\section{Introduction}

Dyspepsia is a chronic disease characterized by symptoms in the upper gastrointestinal tract [1]. It is also a medical term used to describe the sense of "difficult digestion". The most common symptoms are postprandial fullness, discomfort, early satiation, bloating, belching, nausea, vomiting, or pain. Dyspepsia can be divided into "organic" when an underlying organic disease is likely to be the cause of the symptoms and FD when no organic abnormality is identified (i.e., no apparent specific cause of the symptoms has been found) [2].

Peptic ulcer disease is the most important identifiable organic cause [2], while gastro-esophageal malignancy rarely induces dyspeptic symptoms [3]. The prevalence of peptic ulcers in dyspeptic subjects is $5 \%$ to $10 \%$ [4]. In most cases, peptic ulcers are caused by prolonged use of NSAIDs, stress, excessive consumption of al- cohol and smoking, hereditary predisposition, and infection by the bacteria Helicobacter pylori [5].

On the other hand, patients labeled as having FD make up over three-quarters of individuals [3]. In 1991, the Rome committees, a multinational group of experts, who regularly revise the diagnostic criteria for all functional gastrointestinal disorders, classified FD into ulcer-like dyspepsia, dysmotility-like dyspepsia, reflux-like dyspepsia, and unspecified FD [1]. However, more recently, in the Rome III and IV versions, FD was divided into PDS and EPS, with the stipulation that symptoms must be severe enough to impact the usual activities of the patient at least 1 (EPS) or 3 (PDS) days per week, for at least 6 mo before diagnosis [6]. The pathophysiology of FD is still not completely understood. However, as reviewed by Wauters et al. [6], emerging evidence has pointed out abnormal central modulation (brain to gut) 


$\begin{array}{ll}\text { ABBREVIATIONS } \\ \text { (COX)-2 } & \text { cyclooxygenase-2 } \\ \text { AA } & \text { acetic acid } \\ \text { CAT } & \text { catalase } \\ \text { eNOS } & \text { endothelial nitric oxide synthase } \\ \text { EPS } & \text { epigastric pain syndrome } \\ \text { FD } & \text { functional dyspepsia } \\ \text { GE } & \text { gastric emptying } \\ \text { GPX } & \text { glutathione peroxidase } \\ \text { GSH } & \text { glutathione } \\ \text { GSHR } & \text { ghrelin receptor } \\ \text { H2RA } & \text { H2-receptor antagonist } \\ \text { HSP-70 } & \text { heat shock protein 70 } \\ \text { IL } & \text { interleukin } \\ \text { iNOS } & \text { inducible nitric oxide synthase } \\ \text { MAPK } & \text { mitogen-activated protein kinase } \\ \text { MCP-1 } & \text { monocyte chemoattractant protein } 1 \\ \text { MDA } & \text { malondialdehyde } \\ \text { MMP } & \text { matrix metalloproteinase } \\ \text { NEM } & \text { N-ethylmaleimide } \\ \text { NF-KB } & \text { nuclear factor kappa B } \\ \text { nNOS } & \text { neuronal nitric oxide synthase } \\ \text { NO } & \text { nitric oxide } \\ \text { NOS } & \text { nitric oxide synthase } \\ \text { NP-SH } & \text { nonprotein sulfhydryl groups } \\ \text { NSAIDs } & \text { non-steroidal anti-inflammatory drugs } \\ \text { PDS } & \text { postprandial distress syndrome } \\ \text { PGs } & \text { prostaglandins } \\ \text { PPIs } & \text { proton pump inhibitors } \\ \text { SDS } & \text { single dyspepsia symptom } \\ \text { SOD } & \text { superoxide dismutase } \\ \text { TGF- } \beta 1 & \text { transforming growth factor- } \beta 1 \\ \text { TNF- } \alpha & \text { tumor necrosis factor- } \alpha \\ \text { TRPV } & \text { transient receptor potential vanilloid } \\ \text { VIPR2 } & \text { vasoactive intestinal peptide receptor type 2 } \\ & \end{array}$

and overactive visceral sensory signaling (gut to brain), intestinal inflammation, and systemic immune activation.

The quality of life of patients experiencing dyspepsia and FD is significantly affected [2], but the current pharmacological treatment options are mainly based on PPIs, $\mathrm{H}_{2} \mathrm{RA}$, and $\mathrm{H}$. pylori eradication. Antidepressants are used after the failure of the abovementioned treatments, especially amitriptyline. Because motility disorders are a possible underlying cause of FD, prokinetics can also be considered for treatment [7]. However, all these options are of limited efficacy and target the symptoms and gastric sensorimotor function rather than the underlying pathology [6]. Thus, up to $50 \%$ of patients with FD seek other forms of treatment, such as medicinal plants [1].

As complementary and alternative therapies are well accepted for dyspepsia management, where conventional treatments have proven ineffective, we have looked to new medicinal plants with the potential to treat dyspepsia and FD. Some herbal medicines have already been investigated in randomized controlled clinical trials, of which we highlight Mentha pulegium [8], Nigella sativa [9], and STW5 [10]. Considering the pathophysiologic of organic and FD, we present, in this work, the studies published between 2017 and 2020 on plant species with gastroprotective and antiH. pylori activities, as well as those used to treat FD (i.e., with prokinetic efficacy), grouping them by their molecular mechanisms or mode of action.

\section{Methodology}

Systematic screening in the databases PubMed (https:// www.ncbi.nlm.nih.gov/pubmed), Science Direct (http://www. sciencedirect.com/), and Medline (https://www.nlm.nih.gov/bsd/ pmresources.html) was used to search on articles published between 2017 and 2020. The keywords "natural product" or "medicinal plant" in a cross-over with the terms "dyspepsia" or "functional dyspepsia" (i.e., gastroprotection, H. pylori infection, prokinetic) were used to create this review. First, we looked at the titles and abstracts. We then screened the texts in full to check for their suitability. The authors debated any disagreement.

Studies that met the following criteria were included: (1) preclinical and clinical trials that report consistent effectiveness data; (2) manuscripts for which the full text was available; and (3) studies written in English. The following studies were excluded: (1) studies with no satisfactory efficacy results; (2) preliminary studies reporting only gastroprotective effect with no data pointing out the mode or mechanism of action; and (3) case reports, conference abstracts, review articles, editorials, and letters to the editor.

\section{Therapeutic Potenzial of Medicinal Plants in Dyspepsia}

\section{Gastroprotective medicinal plants and their potential to alleviate dyspepsia}

In the last 3 years, medicinal plants have been studied for their gastroprotective properties. Most of them are based on the traditional use of genera or species to treat gastrointestinal disorders, while others are based on previous reports in this pharmacological field. However, the reader is referred to the notion that, due to the pleiotropic actions of multi-constituent plant extracts, an exclusive assignment to a single-mode action often cannot live up to the full polypharmacology inherent to a given herbal remedy. To avoid redundancy, though, we name plants only once in an appropriate mode-of-action subchapter but also mention other bioactivities as far as known.

Table 1S (Supporting Information) summarizes the preclinical studies of plant species with gastroprotective properties, highlighting the official name of each plant, the type of extract used in the study, the part of the plant used, the methodological model employed, the doses and treatment times, the mechanism of action or the mode of action in the absence of an elucidated mechanism, and finally, the isolated compounds responsible for the plant effect.

In most of the studies reviewed, the treatments were administered before the harmful agent; hence, they are considered mod- 
els of gastroprotection. In some studies, pretreatments were administered for 3 to 30 days before ulcer induction. Although this long treatment time is not explained in the studies, some of these extracts are suggested to have adjuvant properties or even potential for development as food supplements. In dyspepsia management, approaches to prevent the onset of symptoms are interesting, but it is known that long-term treatments are challenging and can bring more adverse effects; therefore, as the gastroprotection models are acute, we highlight the more significant potential of those products that were tested in a single administration and at lower doses.

Interestingly, most of the 39 plants displayed in Table 1S (Supporting Information) and highlighted for their gastroprotective effects have been used in traditional medicine to treat gastrointestinal disorders, including dyspepsia. However, the molecular mechanisms of the species have been little explored. Most studies only disclose the mode of action of the species, which often involves modulation of inflammation and oxidative stress, PGs, and anti-apoptotic or antisecretory effects.

\section{Gastroprotective plants that modulate oxidative and inflammatory parameters}

Pretreatment with methanol extract of Chasmanthera dependens (Hochst) stem (Menispermaceae) reduced gastric lesions induced by indomethacin in rats. $C$. dependens extract demonstrated the ability to complement and maintain the antioxidant enzymes of the gastric mucosa, preventing lipid peroxidation [11]. In this study, and in most of the others that will be discussed in the following paragraphs, the mechanisms of action that lead to the antioxidant and/or anti-inflammatory effects were not revealed. Therefore, it is not possible to infer whether such effects are pivotal for the effects of the plant or its consequence.

In Iranian folk medicine, Achillea wilhelmsii (Asteraceae) is used to treat gastric ulcers. Koushki et al. [12] suggested that the extract of $A$. wilhelmsii could heal indomethacin-induced gastric ulcers. However, the authors evaluated the gastroprotective activity of $A$. wilhelmsii without using any canonical model to verify its effect on gastric healing. Furthermore, although antioxidative and anti-inflammatory effects are suggested as probable mechanisms underlying the anti-ulcerative and ulcer-healing properties of A. wilhelmsii, this conclusion was based on an observational correlation with the maintenance of gastric mucosa protein levels of Alb, Fabp5, Hspb1, Tagln, Lgals7, Csta, and Myl9 and the metabolites found in the extract. Therefore, further studies are needed to assess the mechanisms of action.

The seeds of Persea americana Mill., known as "avocado", Lauraceae family, showed gastroprotective activity against the indomethacin-induced gastric ulcer model in mice, mediated by increased endogenous antioxidant enzyme activity and mucus production, and decreased oxidant factors and inflammatory process [13]. The bark infusion of another plant of the same genus, Persea major (Meisn.) L.E. Kopp, popularly known as "Pau de Andrade", is commonly used to treat ulcers in traditional medicine. In this regard, Somensi et al. [14] showed that $P$. major bark reduced acute gastric lesions induced by ethanol and indomethacin in rodents. Treatment with the extract for 7 days also promoted gastric healing of lesions caused by AA. The gastroprotec- tive effect of the extract was proven to be dependent on the NO and NP-SH. The gastric healing property was simultaneously accompanied by increased mucus production.

The effect of the fresh fruit peel of Citrus sinensis L. ("orange"), a member of the Rutaceae family, has also been studied. Selmi et al. [15] demonstrated that pretreatments with $C$. sinensis and its major flavonoid, hesperidin, protected the gastric mucosa against ethanol-induced damage in rats. Both extract and hesperidin exerted anti-inflammatory and antioxidant properties, decreased (COX)-2 expression and gastric DNA fragmentation, and reduced TNF- $\alpha$ production and lipid peroxidation.

Aronia melanocarpa (Michx.) Elliot. (Rosaceae) fruits, known as "black chokeberry", inhibited gastric injury induced by ethanol in rats in a manner dependent on NO, opioid receptors, TRPV, and PGs. Therefore, it was shown that the extract decreased the inflammatory process, reduced MCP-1, MDA, NF- $\kappa$ B, and TNF- $\alpha$ levels, and increased SOD, CAT, and GPX activity and upregulation of the IL-4, HSP-70, NO, and PGE 2 expressions. The authors concluded that the gastroprotective effect of $A$. melanocarpa might be due to the downregulation of TNF- $\alpha$-based NF- $\kappa$ B, MCP-1 signaling, and its significant antioxidant properties [16]. It is worth mentioning that patients with FD have been shown to have visceral chemohypersensitivity involving the TRPV1 pathway [17]. Although the role of TRPV1 in the pathophysiology of dyspepsia still requires further clarification, drugs acting in this pathway could be a promising approach for future studies.

Aloe vera (L.) Burm. f. (Xanthorrhoeaceae) showed gastroprotective effect in a Balb/c mouse model of ethanol-induced acute gastritis. While it showed no acid-neutralizing capacity, it inhibited mRNA and protein expression levels of matrix MMP-9, iNOS, and nNOS in the gastric mucosa [18], indicating anti-inflammatory action.

In Taiwan, Corchorus capsularis L. (Malvaceae) leaves have been popularly used as food and for their gastroprotective properties. A study showed that it decreased the ulcer index caused by ethanol in rats in a dose-dependent manner, an effect associated with its antioxidant activity through increased GPX, SOD, and CAT activity and decreased MDA levels in serum samples [19].

Barbosa et al. [20] found that Avicennia schaueriana Stapf \& Leechmn. ex. Moldenke (Acanthaceae) leaves, a plant used in Brazilian folk medicine to treat gastric disorders, has gastroprotective effects on $\mathrm{HCl} /$ ethanol-induced model in rats. Moreover, it was suggested that the NO and NP-SH groups, but not PGs, are pivotal to this action. Similarly, treatment with Ardisia crispa Thunb A.DC roots (Primulaceae), a species commonly known as "hen's eyes", has demonstrated gastroprotective activity against ethanol, also through the involvement of NP-SH groups. In that study, both the anti-arthritic and gastroprotective effects of the plant were partially attributed to its antioxidant properties [21].

Pilosocereus gounellei (F. A.C Weber ex K. Schum.) Byles \& G.D. Rowley, a member of the Cactaceae family, known as "xiquexique", is used in Brazilian folk medicine to treat gastritis [22]. Sousa et al. [22] therefore evaluated its antiulcer activity. They found that it exhibited a significant gastroprotective effect in ethanol, ischemia-reperfusion, and cold restraint stress-induced gastric lesion models, possibly involving the participation of NO, 
PGs, and NP-SH. Nevertheless, this activity does not seem to be related to an antisecretory mechanism.

Dioscorea batatas Decne, known as "Chinese yam." showed a gastroprotective effect against ethanol/HCl-induced acute gastric damage in mice. In addition, the extract significantly decreased the expression of (COX)-2 while restoring heme oxygenase- 1 (HO- 1 ) expression and SOD activity in the gastric tissue. Based on these results, the authors suggested that $D$. batatas effects are mediated by activating the antioxidant system and suppressing inflammatory response [23].

Croton rhamnifolioides Pax (Euphorbiaceae) (syn. Croton heliotropii folius Kunth and Hoffm), popularly known as "caatinga branca" or "quebra faca", is another plant species that have been used in folk medicine to treat ulcers. In fact, the gastroprotective activity of $C$. rhamnifolioides against absolute ethanol, acidified ethanol, or indomethacin has been demonstrated. The participation of the NO and opioid pathways were the mechanisms involved in this effect, and no significant toxicity was observed [24].

Members of the genus Erythrina have traditionally treated various ailments, such as inflammation and gastrointestinal disorders. Erythrina speciosa var. rosea N. F. Mattos (Fabaceae) leaves reduced ethanol-induced gastric-ulcer model in rats, elevating mucin production. These effects were partially mediated by the potent anti-inflammatory activity of the fraction, as evidenced by the reduction in the immunoexpression of NF- $\mathrm{B}$, COX-2, iNOS, and oxidative stress markers [25].

Geranium koreanum Kom. (Geraniaceae) is one of the Geranium species known as "Geranii Herba". It was recently demonstrated that $G$. koreanum inhibited gastric damage induced by ethanol/ $\mathrm{HCl}[26]$. The authors proposed that $G$. koreanum improves the inflammation response by suppressing the production of inflammatory proteins in the NF- $\kappa$ B and MAPK signaling pathways in the gastric mucosa, based on their findings on NF- $K B$ protein expression measured in RAW264.7 cells stimulated with LPS and treated with the extract. LPS-activated RAW264.7 cells are a canonical model for inflammation research. LPS stimulation can release the inhibitory protein $\mathrm{I} \mathrm{B}$ bound in the NF- $\kappa \mathrm{B}$ complex, allowing NF- $\kappa \mathrm{B}$ to translocate from the cytoplasm to the nucleus $[27,28]$. Although RAW264.7 cells are a monocyte/macrophage-like cell linage derived from BALB/c mice and are described as capable of pinocytosis and phagocytosis, these results may differ in humans; cautious interpretation of data obtained from experiments performed only on cell lines is necessary [29,30].

Similarly, the hydroalcoholic extract of the fruits of Camellia japonica, a plant of the Theaceae family, known as "dongbae", has been shown to mitigate inflammation and maintain normal gastric mucosal integrity in LPS-induced inflammation in RAW 264.7 cells and the ethanol/HCl-induced gastric ulcer in mice, respectively. The effect of $C$. japonica was attributed to a blockade of pro-inflammatory signaling mediated by MAPK/NF- $\kappa$ B pathways in vivo [31].

Rabdosia inflexa (Lamiaceae), known as "sanbakha”, has been used in folk medicine to treat gastrointestinal inflammation and pain. The extract of $R$. inflexa aerial parts showed a gastroprotective effect against ethanol/HCl in mice. $R$. inflexa mitigated gastric oxidative stress and decreased gastric inflammation. The extract markedly attenuated MAPKs phosphorylation and COX-2 expres- sion, with degradation of inhibitor kappa $\mathrm{B}({ } \kappa \mathrm{B} \alpha)$, and activation of NF- $\kappa$ B. Interestingly, it also significantly inhibited phosphorylation of $\mathrm{I}_{\kappa} \mathrm{B} \alpha$ and NF- $\kappa \mathrm{B}$ p65 in RAW 264.7 cells. Thus, it was proposed that $R$. inflexa may inhibit the early steps of inflammation and modulate the upregulation of pro-inflammatory cytokines through suppression of NF- $\kappa$ B translocation [32].

Al-Quraishy et al. [33] showed that Olea europaea (Oleaceae) leaves, commonly known as "olive", could protect the gastric mucosa against ethanol/HCl-induced damage in rats. Olive extract attenuated ethanol-induced inflammatory response by decreasing NF- $\kappa \mathrm{B}, \mathrm{COX}-2$, and TNF- $\alpha$ expressions and down-regulating iNOS and IL- $1 \beta$ in the gastric mucosa. The gastroprotective mechanism of olive involved antioxidant activity, chiefly through NF-kB inhibition and increased Nrf2 mRNA expression.

Artemisia capillaris (Compositae) aqueous extract has been shown to reduce ethanol/ $\mathrm{HCl}$-induced gastric damage in rats by inducing SOD activation and reducing inflammatory cytokines, such as IL-1 $\beta$ and IL-6, through NF- $K B$ downregulation. The proposed mechanism was confirmed by in vitro studies in which the extract was shown to inhibit IL- 6 and IL- $1 \beta$ in LPS-stimulated murine macrophages by downregulating NF-KB [34].

The species Kalanchoe brasiliensis Cambess and Kalanchoe pinnata (Lamarck) Persoon, members of the Crassulaceae family, popularly known as "coirama” and "saião", respectively, are popularly used to treat peptic ulcers. Indeed, they protected the mucosa against indomethacin and ethanol-induced gastric damage in rats. Interestingly, the leaf juices were not filtered; thus, the pharmacological tests were conducted similarly to their widespread use, as reported by the local population. Pretreatment with $K$. brasiliensis and $K$. pinnata led to the upregulation of ZO- 1 and the downregulation of iNOS and NF-kB-p65, showing a cytoprotective effect in maintaining mucus production [35].

The emerging evidence has shown that dyspepsia is related to immune activation, stimulated by stress or gastric and intestinal inflammation $[6,36]$. Therefore, NF- $k$ B signaling modulation increases the relevance of the species $G$. koreanum, C. japonica, $R$. inflexa, O. europaea, A. capillaris, K. brasiliensis, and K. pinnata.

\section{Gastroprotective plants with prostaglandin-dependent effect}

According to the studies investigated, one way to strengthen the gastric mucosal barrier functions is by stimulating mucus production through the action of PGs on gastric cells [37]. Also, carbenoxolone, a semisynthetic triterpenoid often used as a positive control in experimental models of gastroprotection, acts partly through the participation of endogenous PGs [38]. Therefore, in this subchapter, we grouped the plant species highlighted in the studies for their prostaglandin-dependent effects, although other pathways are often described together.

The gastroprotective effect of hexane extract of Ocimum basilicum L. ("sweet basil”, family Lamiaceae) in aspirin-induced gastric ulcers in mice, and its ameliorative effect on behavioral alterations, were studied. Extract of $O$. basilicum demonstrated anxiolytic, antioxidant, and anti-inflammatory effects. The results showed that modulation of pro-and anti-inflammatory cytokines, inhibition of lipid peroxidation, and the enhancement of antioxidant parameters and PGs are involved in the mode of action of the extract 
[39]. However, these conclusions were drawn based on parameters analyzed in animal serum and cannot be inferred as a mechanism of action but possibly a consequence of it. Moreover, it should be noted that FD has been associated with stress, anxiety, and depression [40]; therefore, products like this, with associated gastroprotective and anxiolytic effects, are interesting alternatives to be explored in this field.

A wide variety of Bauhinia genera (Leguminosae), known as "Pata-de-Vaca", are used in Brazilian folk medicine due to their gastroprotective properties. Extracts from B. curvula leaves reduced ethanol/ $\mathrm{HCl}$ and indomethacin-induced gastric ulcer in rodents, an effect that was abolished in mice pre-treated with $\mathrm{N} \omega$ Nitro-L-arginine methyl ester (L-NAME), NEM, glibenclamide, or indomethacin, pointing to the pivotal role of the NO, NP-SH; $\mathrm{K}_{\text {ATP }}$ channels, and PGs in the effect of the species. On the other hand, it did not alter volume, $\mathrm{pH}$, total acidity, or pepsin activity of gastric acid secretion in rats nor did it inhibit in vitro $\mathrm{H}^{+}, \mathrm{K}^{+}$-ATPase activity. Additionally, 2 compounds identified and isolated-the flavonoids quercitrin and kaempferol-could decrease the extent of ulcerated area induced by both ethanol/ $\mathrm{HCl}$ and indomethacin [41].

Tocoyena formosa (Cham. \& Schlecht.) K. Schum (Rubiaceae), popularly known as "Jenipapo do campo", is another plant used in traditional medicine for inflammatory morbidities and gastric symptoms. T. formosa demonstrated a gastroprotective effect on ethanol, ethanol $/ \mathrm{HCl}$, and indomethacin-induced gastric lesions in mice. The authors have suggested that $T$. formosa may increase PGs, thereby stimulating mucus-bicarbonate secretion and forming a protective mucosal barrier. However, although the mucus increase was observed experimentally, no other experiment has been carried out to assess PG levels [42].

Moreover, Chrysophyllum cainito L. (Sapotaceae) fruits, known as "star apple" or "abiu-roxo", have demonstrated a gastroprotective effect against ethanol/HCl and indomethacin. Regarding the mode of action, the gastroprotective effect of the peel was dependent on NP-SH, K $\mathrm{K}_{\text {ATP }}$ channels, $\alpha$-adrenergic receptors, and PGs. The gastroprotective effect of the seeds was dependent on $\mathrm{NP}$-SH, $\mathrm{K}_{\text {ATP }}$ channels, NO, and $\alpha$-adrenergic receptors. At the same time, the pulp had a gastroprotective effect that was dependent on NP-SH and NO. None of the extracts caused reduced gastric acid secretion. Moreover, supplementation with the flour from C. cainito fruit at $10 \%$ for 7 days but not the juice intake displayed gastroprotective potential, showing that the fruit is a promising functional food [43].

In Brazilian folk medicine, the infusion/decoction of Cochlospermum regium (Mart.ex Schrank) Pilg. is used for many purposes, including gastritis, ulcers, and intestinal inflammation. Arunachalam et al. [44] studied its medicinal plant's gastroprotective and gastric healing effects based on this use. C. regium promoted a protective effect against acute ulcers induced by ethanol $/ \mathrm{HCl}$, piroxicam, and water restraint stress. In the chronic gastric ulcer model induced by AA, the extract also decreased the injured area by regenerating the gastric mucosa and reducing inflammation and oxidative stress. It also increased mucus production and altered the gastric secretion parameters. The authors also suggested that gallic acid, rutin, morin, myricetin, and kaempferol compounds, which were found in substantial amounts, are likely to be responsible for the gastroprotective and antiulcer activities of the species. However, as a negative point of the present study, it is notable that none of the compounds was tested in isolation. Finally, the authors point out that the underlying mechanisms of this antiulcerogenic action involved stimulation of PGs and NO synthesis, in addition to activation of the K+ATP channels, $\alpha$-2-adrenergic receptors, and antioxidant activity, supported by the lacking effect of the extract in animals pre-treated with indomethacin, L-NAME, glibenclamide, and yohimbine respectively. Although the extract also prevented mucus depletion, PG levels were not quantified in the gastric mucosa.

The hydroethanolic extract of Caryocar coriaceum Wittm. (Caryocaraceae) leaves, known as "Pequizeiro", decreased the lesions induced by ethanol, ethanol/ $\mathrm{HCl}$, indomethacin, and $\mathrm{AA}$. It was demonstrated that opioid receptors, $\alpha 2$-adrenergic receptors, and primary afferent neurons sensitive to capsaicin were involved in the mechanism of gastric protection, in addition to the contribution of NO and PGs [45]. However, similarly to the study mentioned previously, PGs levels were not evaluated.

\section{Gastroprotective plants with anti-apoptotic effects}

Total triterpenes from the Chaenomeles speciosa (Sweet) Nakai (Rosaceae), also known as "mugua", showed gastroprotective property against indomethacin-induced gastric damage in vitro on GES-1 cells and in vivo in rats. Further studies showed that C. speciosa triterpenes downregulated miR-423-5p mRNA, NAG-1 mRNA and protein expression, Bax, Bad, cytosol cytochrome C, Apaf-1, cleaved-caspase-3, and cleaved-caspase- 9 protein expression, and cytosol cytochrome $C$ concentration. It also upregulated TFF1, TFF2, and TFF3 mRNA and protein expression, Bcl-2, Bcl-xl, pro-caspase-3, and pro-caspase-9 protein expression, mitochondrial viability, mitochondrial cytochrome $C$ concentration, and $\mathrm{Bcl}-2 / \mathrm{Bax}, \mathrm{Bcl}-\mathrm{xl} / \mathrm{Bad}$ ratios. Therefore, these findings demonstrated that $C$. speciosa triterpenes protected against indomethacin-induced gastric damage by depressing miR-423-5p expression and modulating the TFF/NAG-1 pathway, which in turn, restrained mitochondrion-mediated apoptosis [46, 47].

Pretreatment with Salvadora persica L. (Salvadoraceae, known as "miswak") showed a gastroprotective effect against damage induced by ethanol in rats. S. persica extract exerted antiulcer activities via modulation of oxidant/antioxidant status, mitigation of pro-inflammatory cytokines, and apoptosis, as well as remodeling NOS isoforms, as visualized by upregulated eNOS and TGF- $\beta 1$ gene expression and downregulation of TNF- $\alpha$ and IL- $1 \beta$ genes, as well as Bax and iNOS [48]. The specific mechanism responsible for producing these effects has not been described.

Prunus armeniaca L. (Rosaceae) kernel oil, “apricot”, also showed a gastroprotective effect on ethanol-induced gastric ulcer in rats by its anti-inflammatory, antioxidant, and anti-apoptotic effects, as observed by a decreased number of iNOS and TUNEL positive cells and MDA and IL-6 levels in the gastric mucosa [49].

Treatment with Actinodaphne sesquipedalis Hook. F. Var. Glabra (Kochummen), Lauraceae family, known as "Medang payung", also demonstrated a gastroprotective effect against ethanol-induced ulcers in rats. The extract prevented gastric mucosa disruption by increasing gastric $\mathrm{pH}$ and mucus content and decreasing oxidative stress and inflammation, in addition to suppressing 
apoptosis through the upregulation of HSP-70 and downregulation of Bax protein [50].

Cibotium barometz (L.) J Sim (Cibotiaceae), also known as "Golden Hair Dog Fern", is another medicinal herb used traditionally in the Malaysian peninsula for several ailments, including gastric ulcer treatment. C. barometz demonstrated a gastroprotective effect in the ethanol-induced ulcer model. This effect was attributed to increased antioxidant activity, mucus preservation, upregulation of HSP-70, and downregulation of Bax proteins [51]. Similarly, C. barometz leaves also demonstrated a gastroprotective effect against ethanol-induced gastric ulcers in rats, an effect attributed to upregulated HSP-70 expression and downregulation of $\mathrm{Bcl}-2$ protein expression [52].

Except for the study referring to $C$. speciosa, none of the other studies mentioned above enable us to conclude as to whether the anti-apoptotic effects are the mode of action of the extracts or simply a consequence of an overall antioxidant and anti-inflammatory effect that culminates in a reduction in gastric lesions and apoptosis.

\section{Gastroprotective plants with antisecretory effects}

Dyspepsia, and the gastrointestinal dysfunctions related to it, such as gastric and duodenal ulcers and GERD, are mainly induced by abnormal gastric acid secretion from parietal cells of the digestive tract $[53,54]$. Thus, suppressing excessive gastric acid secretion and reinforcing the gastric mucosal barrier function are promising approaches in treating dyspepsia.

The leaves of Plinia edulis (Vell.) Sobral (Myrtaceae), known as "cambuca", are also indicated in the treatment of gastric disorders, according to Brazilian folk medicine, and scientific evidence has proven its gastroprotective effect [55]. More recently, its fruits were evaluated by da Rosa et al. [56]. The extract of peels from $P$. edulis fruit and the isolated triterpenes maslinic and ursolic acids demonstrated gastroprotective effects against acidified ethanol and indomethacin in mice. The extract and maslinic acid inhibited $\mathrm{H}^{+}, \mathrm{K}^{+}$-ATPase activity in vitro, whereas ursolic acid favored the mucus barrier [56]. Although acid suppression seems to be a worthwhile strategy in most patients with FD [1], it is noteworthy that PPIs are frequently scrutinized due to overprescription and their potential long-term adverse events [6]. Besides, PPI- induced dysbiosis has been described as limiting the efficacy of this class of drugs in the first-line treatment of FD [57].

Caesalpinia sappan Linn. (Caesalpiniaceae) is commonly known as "Brazil" or "Sappan Wood" and "Bakam" or "Patang" in Hindi. Treatment with $C$. sappan demonstrated a gastroprotective effect against ethanol, indomethacin, and pylorus ligation-induced ulcer in rats. These effects were mediated by the improved antioxidant status of the gastrointestinal system, mucus secretion, reduced inflammatory mediators, and gastric secretion inhibition, which were related to increased COX expression, $\mathrm{PGE}_{2}$ synthesis, decreased iNOS expression, and the inhibitory effect on $\mathrm{H}^{+} / \mathrm{K}^{+}$ATPase [58].

In rats, the leaves of Cordia dichotoma (Boraginaceae) showed a dose-dependent gastroprotective effect against indomethacin and stress-induced gastric ulceration. The findings of a study revealed that $C$. dichotoma extract reduced gastric volume, total acidity, and gastric mucosal damage in both the experimental models compared with the control group. Moreover, its antioxidant and anti-inflammatory effects also mediated the gastroprotective effect of the species [59]. It is important to note that up to half of subjects with uninvestigated dyspepsia in the general population identify stress as a trigger for their symptoms [60], reinforcing the medicinal potential of the species, which displays gastroprotective effects against this etiological agent.

Melastoma malabathricum L. (Melastomaceae) is another medicinal plant that is traditionally used to treat gastric ulcers. In a study conducted by Ismail Suhaimy et al. [61], M. malabathricum leaves showed the most significant gastroprotection activity against the ethanol-induced gastric ulcer model. This effect was $\mathrm{NO} / \mathrm{NP}-\mathrm{SH}$-dependent and was attributed to antisecretory and antioxidant activities and stimulation of gastric mucus production.

In folk medicine, the plant Celastrus paniculatus Willd (Celastraceae) has also been used to prevent and treat gastrointestinal disturbances, including dyspepsia and stomach ulcers. C. paniculatus seed oil demonstrated effective gastroprotection against ethanoland indomethacin-induced ulcer models. In pylorus-ligated rats, the seed oil showed gastroprotective activity by decreasing total gastric juice volume and gastric acidity while increasing the gastric $\mathrm{pH}$. The gastroprotection against ethanol and indomethacin was partially attributed to the effective inhibition of pro-inflammatory cytokines and oxidative stress. Additionally, C. paniculatus seed oil reduced the GE rate but did not affect gastrointestinal transit [62]; however, considering that delayed GE is a defining feature of gastroparesis, present in up to $35 \%$ of FD patients [63], this type of effect is not desirable.

The stem bark of Virola elongata (Benth.). Warb. (syn. Virola cuspidate (Benth.) Warb.) is used in Brazilian and Ecuadorian indigenous folk medicine to treat stomach pain, indigestion, and gastric ulcers. Treatment with $V$. elongata reduced the gastric lesions induced by ethanol/ $\mathrm{HCl}$, piroxicam, and water restraint stress-induced ulcer. Moreover, treatment with the extract promoted gastric healing in animals under gastric ulcers induced by $A A$. The antiulcer effects of $V$. elongata seemed to involve antioxidant activity and antisecretory actions [64]. Nonetheless, the studies do not describe the antisecretory mechanisms of $C$. dichotoma, M. calabura, C. paniculatus, and V. elongata.

\section{Medicinal plants with potential effects against $H$. pylori infection}

The quality of life of patients with dyspepsia and FD is significantly affected [2]. The current FD pharmacological treatment options are mainly based on PPIs, $\mathrm{H}_{2} \mathrm{RA}$, and $\mathrm{H}$. pylori eradication.

The bacterium $H$. pylori colonizes both the corpus and antrum of the stomach, leading to severe complications, ranging from gastritis to severe gastric cancer [65]. Although this microorganism is susceptible to several antibiotics in vitro (such as clarithromycin, metronidazole, amoxicillin, and tetracycline), effectively abolishing this bacterium is considered a significant challenge in clinical practice. The supposed reason for this problem is that antibiotics penetrate the infected mucosa to contact the bacteria [66, 67], limiting drug efficacy. However, there is recent evidence of plant species that can eradicate $H$. pylori infection, an approach that is equivalent to treatment with antibiotics. This may repre- 
sent a future therapeutic alternative in the development of new drugs. A summary description of plant species with anti-H. pylori effects is given in $>$ Table $\mathbf{1}$.

Park et al. [68] recently reported the effects against $H$. pylori of 2 plants, Rubus crataegifolius Bunge (RF) and Ulmus macrocarpa Hance (UL), of the family Rosaceae and Ulmaceae families, respectively, using in vitro and in vivo approaches. First, the authors demonstrated a marker for each extract analyzed through the ellagic acid and catechin-7-O- $\beta$-D-apiofuranoside content, respectively. The results obtained after the in vitro growth condition against $2 \mathrm{H}$. pylori standard strains and 11 clinical isolates revealed that RF and UL extracts completely inhibited the colonization of $H$. pylori. Both isolated compounds, ellagic acid and catechin-7-O- $\beta$-Dapiofuranoside, totally suppressed the colonization of $H$. pylori. Also, the $H$. pylori $\left(0.5 \mathrm{~mL}, 2 \times 10^{8} \mathrm{CFU} /\right.$ animal) inoculated Balb/c mice model was used to assess the effect of the extracts under in vivo conditions. After $4 \mathrm{wk}$ of $H$. pylori inoculation, the animals were treated daily with RF or UL. After 4 wk of treatment (i.e., at the end of the eighth wk after inoculation of the bacteria), the gastric lesions were analyzed. In the $H$. pylori-induced gastritis model, both treatments showed moderate effect against bacterial infection, confirming the efficacy of these 2 plant species in treating $H$. pylori.

Desmostachya bipinnata (L.) Stapf (family Poaceae) has been used in folk medicine to treat many diseases, including gastric ulcers. The in vitro effect of extracts of different plant species against $H$. pylori infection was described [69]. The authors used 12 clinical yields of $H$. pylori isolated from biopsies received from patients diagnosed with gastritis or peptic ulcers. The most effective preparations against $H$. pylori were ether, ethanol, and n-butanol extracts, which showed inhibition of $75 \%, 75 \%$, and $66.7 \%$, respectively. Although the results obtained are only in vitro and with high effective concentrations of extracts, the authors suggest that the aerial parts of $D$. bipinnata can be considered a potential natural medicine.

Hwanglyeonhaedok-tang (HHT), also known as Huang-Lian-JieTang or Orengedoku-to, is popularly used in the folk medicine of East Asian countries. It consists of 4 plant species: Phellodendron bark (Phellodendron amurense or $P$. chinense), Scutellaria baicalensis root, Gardenia jasminoides fruit, and Coptis rhizome (rhizome of Coptis japonica, C. chinense, C. deltoidea, or C. teeta) [70]. The authors tested the HHT aqueous extract using in vitro and in vivo approaches. First, they demonstrated the presence of the compounds geniposide, coptisine $\mathrm{Cl}$, baicalin, palmatine $\mathrm{Cl}$, berberine $\mathrm{Cl}$, wogonoside, baicalein, and wogonin in the HHT extract. Of these compounds, geniposide and baicalin were found in quantities of 98.18 and $74.09 \mathrm{mg} / \mathrm{g}$, respectively, suggesting that the preparation effects may be directly related to the high concentrations of these compounds. In vitro studies demonstrated that HHT inhibited the growth of all tested $\mathrm{H}$. pylori strains and was able to significantly inhibit (by $15 \%$ to $70 \%$ ) the adhesion of $\mathrm{H}$. pylori to human gastric carcinoma cells. For the in vivo studies, male C57BL/6 mice were orally infected with $H$. pylori $\left(5 \times 10^{9} \mathrm{CFU} /\right.$ $0.2 \mathrm{~mL} /$ mouse) or vehicle 3 times at 2-day intervals. The mice received $\mathrm{HHT}$ by gavage once daily from wk 4 to 8 . This approach demonstrated that HHT treatment significantly reduced $H$. pylori colonization, inflammation, and the levels of cytokines, cyclooxy- genase 2 and inducible NO synthase in the gastric mucosa. Collectively, these results indicate the potential of HHT against $H$. pylori infection, acting through anti-inflammatory and antibacterial mechanisms.

Allium hookeri Thwaites (Amaryllidaceae) is another popular species used in Asia for food and as herbal medicine. The in vitro and in vivo antibacterial activities of $A$. hookeri extract were described [71]. The composition of the extract revealed the presence of alliin, which would account for its effects. The extract inhibited bacterial growth with an inhibition zone of $20.6 \mathrm{~mm}$. Similar results were obtained for alliin, with an inhibition zone of $15.6 \mathrm{~mm}$. For the in vivo study, the C57BL/6 mice were inoculated with $1.0 \times 10^{9} \mathrm{CFU} H$. pylori 3 times at 3-day intervals and received the treatment with the extract of $A$. hookeri for 4 wk. All the treatments effectively reduced the colonization of $H$. pylori in the stomach, an effect associated with a decrease in mucosal inflammation and epithelial damage, suggesting that this species could be a promising treatment for patients with gastric complaints.

Prazeres et al. [72] evaluated the gastric effects of Libidibia ferrea Mart. ex Tul. (Leguminosae) extract, a plant popularly used to treat gastric problems by communities of the Amazon and the Northeast region of Brazil. HPLC analysis revealed 9 compounds in the extract: galloylquinic acid, galloyl-HHDP-hex, brevifolin carboxylic acid, valoneic acid dilactone, gallic acid derivative, ellagic acid derivative (ellagic acid hex-), ellagic acid, ellagic acid derivative, and dihydroisovaltrate. L. ferrea extract inhibited the gastric ulcers induced by ethanol and indomethacin. The extract also exhibited anti- $\mathrm{H}$. pylori activity, with the minimum bactericidal concentration of $512 \mu \mathrm{g} / \mathrm{mL}$. Despite these positive results, the effects of this preparation remain to be investigated by the in vivo model of gastritis induced by $H$. pylori, and an in-depth analysis of the mechanisms and compounds related to the effects found is necessary.

Casearia sylvestris Swartz (Salicaceae), known as "guaçatonga" in Brazil, is primarily used to alleviate gastric complaints in Brazilian folk medicine. Its effects were evaluated by Spósito et al. [73]. Extract of the leaves of $C$. sylvestris exhibited significant activity against the $H$. pylori strain in vitro. For the in vivo study, Wistar rats first received indomethacin $(20 \mathrm{mg} / \mathrm{kg})$ to induce gastric ulcers. After $24 \mathrm{~h}$, the animals received the $H$. pylori solution containing $6 \times 10^{8} \mathrm{CFU} / \mathrm{mL}$ daily for 7 days. Twenty-four $\mathrm{h}$ after $H$. pylori inoculation, the animals received the $C$. sylvestris extract for 14 days. The results revealed that the ethanolic extract could eradicate $H$. pylori from and reduce the ulcerative lesions.

Paullinia cupana Kunth (Sapindaceae), known as "guarana”, is a native plant species of the Amazon area of Brazil. Its potential effect against $H$. pylori was explored in vitro [74]. The chemical analysis of the $P$. cupana extracts revealed procyanidin, caffeic acid, and its derivatives. Both the crude extract and ethyl-acetate fraction but not the aqueous extract showed inhibitory activity against $H$. pylori in vitro, with MIC of 1024 and $256 \mu \mathrm{g} / \mathrm{mL}$, respectively. Although the study showed significant results, these data are still very preliminary. Further studies are needed to demonstrate the potential of $P$. cupana to control and prevent $H$. pylori infection.

The extracts from the leaves of Bryophyllum pinnatum (Lam.) Kurz (Crassulaceae), a plant known for its antiulcer effects, was 
- Table 1 Medicinal plants with potenzial effects against H. pylori infection.

\begin{tabular}{|c|c|c|c|c|c|}
\hline Plant species/Part used & $\begin{array}{l}\text { Experimental } \\
\text { model }\end{array}$ & Extract/Dose/Concentration & $\begin{array}{l}\text { Mechanism/ } \\
\text { Mode of action }\end{array}$ & $\begin{array}{l}\text { Compounds } \\
\text { tested }\end{array}$ & $\begin{array}{l}\text { Refer- } \\
\text { ences }\end{array}$ \\
\hline $\begin{array}{l}\text { Rubus crataegifolius } \\
\text { Bunge (fruits) }\end{array}$ & $\begin{array}{l}\text { In vitro growth } \\
\text { condition } \\
\text { H. pylori-inocu- } \\
\text { lated Balb/c mice } \\
\text { model }\end{array}$ & $\begin{array}{l}\text { Hydroalcoholic }(150 \mu \mathrm{g} / \mathrm{mL} \text {; } \\
100 \mathrm{mg} / \mathrm{kg})\end{array}$ & - & $\begin{array}{l}\text { Ellagic acid } \\
(50-150 \mu \mathrm{g} / \mathrm{mL})\end{array}$ & {$[68]$} \\
\hline $\begin{array}{l}\text { Ulmus macrocarpa } \\
\text { Hance (stem bark) }\end{array}$ & $\begin{array}{l}\text { In vitro growth } \\
\text { condition } \\
\text { H. pylori inocu- } \\
\text { lated Balb/c mice } \\
\text { model }\end{array}$ & $\begin{array}{l}\text { Aqueous }(200 \mu \mathrm{g} / \mathrm{mL} ; 100 \mathrm{mg} / \\
\mathrm{kg} / \text { day for } 4 \text { weeks) }\end{array}$ & - & $\begin{array}{l}\text { Catechin-7-O- } \beta \text { - } \\
\text { D-apiofurano- } \\
\text { side }(200 \mu \mathrm{g} / \\
\mathrm{mL})\end{array}$ & {$[68]$} \\
\hline $\begin{array}{l}\text { Desmostachya bipinnata } \\
\text { (L.) Stapf (aerial parts) }\end{array}$ & $\begin{array}{l}\text { In vitro growth } \\
\text { condition }\end{array}$ & $\begin{array}{l}\text { Ethanol, ether, chloroform, } \\
\text { ethyl acetate, and n-butanol } \\
(12.5-50 \mathrm{mg} / \mathrm{mL})\end{array}$ & - & - & [69] \\
\hline $\begin{array}{l}\text { Hwanglyeonhaedok- } \\
\text { tang (Coptis rhizome, } \\
\text { Scutellaria root, Phello- } \\
\text { dendron bark, and Gar- } \\
\text { denia fruit) }\end{array}$ & $\begin{array}{l}\text { In vitro growth } \\
\text { condition } \\
\text { H. pylori-inocu- } \\
\text { lated C57BL/6 } \\
\text { mice model }\end{array}$ & $\begin{array}{l}\text { Aqueous ( } 400 \text { to } 1600 \mu \mathrm{g} / \mathrm{mL} \text {; } \\
120 \text { and } 600 \mathrm{mg} / \mathrm{kg} / \text { day for } \\
4 \text { weeks) }\end{array}$ & $\begin{array}{l}\text { Anti-inflammatory } \\
\text { and antibacterial } \\
\text { activity }\end{array}$ & - & [70] \\
\hline $\begin{array}{l}\text { Allium hookeri Thwaites } \\
\text { (dry mass) }\end{array}$ & $\begin{array}{l}\text { In vitro growth } \\
\text { condition } \\
\text { H. pylori-inocu- } \\
\text { lated C57BL/6 } \\
\text { mice model }\end{array}$ & $\begin{array}{l}\text { Hydroalcoholic }(100 \mu \mathrm{gg} / \mathrm{mL} \text {; } \\
25,50 \text {, and } 100 \mathrm{mg} / \mathrm{kg} / \text { day for } \\
4 \text { weeks })\end{array}$ & - & $\begin{array}{l}\text { Alliin } \\
(50 \mu \mathrm{g} / \mathrm{mL})\end{array}$ & [71] \\
\hline $\begin{array}{l}\text { Libidibia ferrea Mart. ex } \\
\text { Tul. (pods) }\end{array}$ & $\begin{array}{l}\text { In vitro growth } \\
\text { condition }\end{array}$ & Hydroalcoholic (512 $\mu \mathrm{g} / \mathrm{mL})$ & - & - & [72] \\
\hline $\begin{array}{l}\text { Casearia sylvestris } \\
\text { Swartz (leaves) }\end{array}$ & $\begin{array}{l}\text { In vitro growth } \\
\text { condition } \\
\text { Indomethacin } \\
\text { plus } \mathrm{H} \text {. pylori-in- } \\
\text { oculated rat } \\
\text { model }\end{array}$ & $\begin{array}{l}\text { Ethanol }(1000 \mu \mathrm{gg} / \mathrm{mL} ; 100 \mathrm{mg} / \\
\mathrm{kg} / \text { day for } 14 \text { days })\end{array}$ & - & - & [73] \\
\hline $\begin{array}{l}\text { Paullinia cupana Kunth } \\
\text { (seeds) }\end{array}$ & $\begin{array}{l}\text { In vitro growth } \\
\text { condition }\end{array}$ & $\begin{array}{l}\text { Crude extract and ethyl-acetate } \\
\text { fraction (1024 and } 256 \mu \mathrm{g} / \mathrm{mL})\end{array}$ & - & - & [74] \\
\hline $\begin{array}{l}\text { Bryophyllum pinnatum } \\
\text { (Lam.) Kurz (leaves) }\end{array}$ & $\begin{array}{l}\text { In vitro growth } \\
\text { condition } \\
\text { H. pylori-inocu- } \\
\text { lated mice model }\end{array}$ & $\begin{array}{l}\text { Methanol }(32-512 \mu \mathrm{g} / \mathrm{mL} ; 250 \\
\text { and } 500 \mathrm{mg} / \mathrm{kg} / \text { day for } 7 \text { days })\end{array}$ & - & - & [75] \\
\hline $\begin{array}{l}\text { Physalis alkekengi L. var. } \\
\text { franchetii (aerial parts) }\end{array}$ & $\begin{array}{l}\text { In vitro growth } \\
\text { condition }\end{array}$ & Ethyl acetate $(500 \mu \mathrm{g} / \mathrm{mL})$ & - & - & [76] \\
\hline $\begin{array}{l}\text { Sphenodesme involucra- } \\
\text { ta var. paniculata (C.B. } \\
\text { Clarke) Munir (leaves) }\end{array}$ & $\begin{array}{l}\text { In vitro growth } \\
\text { condition }\end{array}$ & Methanol $(100 \mu \mathrm{g} / \mathrm{mL})$ & - & - & [77] \\
\hline
\end{tabular}

The values mentioned refer to the minimum inhibitory concentrations for each compound.

tested against $H$. pylori infection [75]. In the in vitro assay, the extracts inhibited the bacterial growth at MIC ranging from 32$256 \mu \mathrm{g} / \mathrm{mL}$. The methanol extract exhibited greater potency in vitro than the ethyl acetate extract, so this was selected for in vivo study. Swiss mice were inoculated with $0.2 \mathrm{~mL}$ of an $\mathrm{H}$. pylori suspension containing $10^{8} \mathrm{CFU} / \mathrm{mL} 4$ times at 2-day intervals, and the treatment with the extract of $B$. pinnatum was administered for 7 days. The treatment with $B$. pinnatum extract significantly re- duced the gastric mucosal bacterial load. Despite these positive results, the effects of this preparation have yet to be investigated in-depth to elucidate the mechanisms and compounds related to the effects found.

Wang et al. [76] investigated the in vitro anti-H. pylori potential of Physalis alkekengi L. var. franchetii (Solanaceae). The P. alkekengi fraction showed significant anti-H. pylori activity with a MIC of $500 \mu \mathrm{g} / \mathrm{mL}$. The mechanisms underlying this effect, and the char- 
acterization of the active compounds involved in the response, remain to be explored in future studies.

The effects of Sphenodesme involucrata var. paniculata (C. B. Clarke) Munir (Lamiaceae) leaves were also evaluated to confirm its antiulcer and anti-H. pylori activities [77]. S. involucrata exhibited a significant range of inhibitory activity against $H$. pylori growth with a MIC of $100 \mu \mathrm{g} / \mathrm{mL}$. In parallel, the extract produced a significant antiulcer effect against ethanol and indomethacin (for details, see [77]). Although the species demonstrated the potential to prevent the onset of gastric ulcers and eradicate $H$. pylori infections, the study did not use in vivo methods to evaluate the protective potential of the preparations against damage caused by $H$. pylori.

Despite the positive results described in this subchapter, most of the preparation effects have yet to be studied in depth to elucidate the mechanisms and compounds related to the effects found. In vivo investigation against $H$. pylori is still required.

\section{Medicinal and edible plants with prokinetic efficacy}

A subtype of FD can be caused by PDS, which is intrinsically linked to disturbed gastric motility due to inadequate fundic accommodation or delayed GE. In these patients, pharmacological therapy is mainly based on prokinetic and fundus-relaxing drugs. Gastroparesis is another disorder characterized by delayed GE but specifically of solid food in the absence of a mechanical blockage in the stomach [78]. The overlap between upper gastrointestinal symptoms makes the differentiation between gastroparesis and FD caused by PDS clinically challenging [36]. FD caused by PDS and gastroparesis share several symptoms; in addition to delayed GE, pathophysiological abnormalities may include accelerated GE, impaired gastric accommodation, and gastric or duodenal hypersensitivity to distension and nutrients [36]. In the last 3 years, different studies have described the prokinetic efficacy of several natural resources with potential as future complementary or alternative therapies for FD, mainly caused by PDS. A summary of the plant species with prokinetic effects is given in > Table 2 .

Chinese herbal medicine has been used to treat FD treatment for thousands of years with satisfactory clinical outcomes. Therefore, Kim et al. [79] investigated the effects of Hwangryunhaedoktang $(\mathrm{HHT})$ on gastrointestinal motility in mice. HHT is traditional Chinese medicine, and those authors also investigated the effects of its 4 components: Gardeniae fructus (GF; Gardenia jasminoides Ellis, Rubiaceae), Scutellariae radix (SR; Scutellaria baicalensis Georgi, Labiatae), Coptidis rhizoma (CR; Coptis chinensis Franch., Ranunculaceae), and Phellodendri cortex (PC; Phellodendron amurense Rupr., Rutaceae) on gastrointestinal motility. The effects were assessed in healthy mice and in mice with gastric dysmotility by AA-induced peritoneal irritation or STZ-induced diabetes. Highlighting the potential of HHT to treat dysfunctional dyspepsia, its oral administration increased the GE in healthy mice and mice with gastric dysmotility. Interestingly, GF, CR, and PC also increased the GE in mice; however, the administration of SR did not alter gastric motility in mice, suggesting that this species is not involved in the effects elicited by HHT. In contrast, the administration of GF accelerated the GE, similarly to HHT. GF has been described as a valuable medicinal plant. The study points out that further investigations are necessary to explore the molecular mechanism and the participation of isolated compounds present in HHT, mainly from GF.

Another study that investigates the efficacy of Chinese herbal medicine to treat FD was performed by Yan et al. [80]. Zhishi is a classic, traditional Chinese medicine used to treat FD. Extract of Weikang pian is composed of flavonoids extracted from zhishi. The authors, therefore, hypothesized that this extract could effectively alleviate the symptoms of FD and performed a randomized, double-blinded, placebo-controlled clinical trial with a sample size of 82 patients to demonstrate this. The study subjects were patients with FD PDS subtype according to the Rome III criteria. Those authors employed a random selection in these patients; moreover, a double-blind experiment and a prolonged drug (4 wk) administration was performed. Two important determinations were made by Yan et al. [80], the SDS scale assessment and the GE function using radiographic quantification. Interestingly, compared with the placebo group, FD symptoms in the group that received Weikang pian ( $400 \mathrm{mg}, 3$ times daily) were relieved after 4 wk of treatment; however, no significant differences in GE parameters were found. This study also performed a phytochemical analysis of Weikang pian, evidencing 3 kinds of flavonoid glycoside by UPLC: naringin (30.20\%), hesperidin (0.84\%), and neohesperidin (36.50\%). However, no hypothesis about the molecular mechanism by which this extract rich in flavonoids promoted its effects has been investigated, which should be addressed in future studies.

The safety and efficacy of a novel formulation of Ferula asafoetida H.Karst. oleo resin and standardized Silybum marianum (L.) Gaertn. extract named Asdamarin on delayed GE was investigated in Sprague Dawley rats using the red phenol method [81]. Oral administration of Asdamarin dose-dependently improved delayed $\mathrm{GE}$, as evidenced by the significant increase in the GIT time $(p<0.001)$. The LD50 of Asdamarin was estimated to be more than $2000 \mathrm{mg} / \mathrm{kg}$, and no clinical signs of toxicity were verified in the rats treated with different doses in a 28-day toxicity study. Also, the chemical analysis of Asdamarin revealed the presence of silymarin and a combination of the flavonoids, including silybin A, silybin B, taxifolin, silychristin, silydianin, isosilybin A, and isosilybin B. Although these data are preliminary, they provided the first evidence of the possible effectiveness of a novel formulation in alleviating functional symptoms associated with dyspepsia. Notably, the antiulcerogenic effect of $F$. asafoetida oleo resin has already been described in the literature [82], and Asdamarin is also helpful in treating FD caused by a gastric ulcer. The modulatory effect of silymarin from S. marianum on NRF2, NF- $\kappa$ B, and apoptosis in an experimental gastric ulcer model [83] also show Asdamarin to be a promising drug for the treatment of FD related to mucosal inflammation.

Extracts of black garlic (Allium sativum L., Amaryllidaceae family) on improved gastrointestinal function were also evaluated [83]. The effects of the ethyl acetate (EA), n-butanol (BA), and the aqueous extracts (AE) from black garlic were verified based on the intestinal motility rate, and acceleration of this parameter was measured by charcoal transit. The results with BA and AE were also confirmed in vitro through the measurement of intestinal contraction. S-allylcysteine (SAC) has been identified as the main component of black garlic extracts [84]; however, SAC incubation 
- Table 2 Medicinal plants with prokinetic efficacy.

\begin{tabular}{|c|c|c|c|c|c|}
\hline Plant species/Part used & $\begin{array}{l}\text { Experimental } \\
\text { model }\end{array}$ & Extract/Dose/Concentration & $\begin{array}{l}\text { Mechanism/ } \\
\text { Mode of action }\end{array}$ & $\begin{array}{l}\text { Compounds } \\
\text { tested }\end{array}$ & $\begin{array}{l}\text { Refer- } \\
\text { ences }\end{array}$ \\
\hline $\begin{array}{l}\text { Hwangryunhaedok-tang } \\
\text { (Gardenia jasminoides J. } \\
\text { Ellis; Scutellaria baicalen- } \\
\text { sis Georgi; Coptis chinen- } \\
\text { sis Franch.; Phelloden- } \\
\text { dron amurense Rupr.) }\end{array}$ & $\begin{array}{l}\text { Acetic acid-in- } \\
\text { duced peritoneal } \\
\text { irritation and } \\
\text { streptozotocin- } \\
\text { induced diabetes }\end{array}$ & $\begin{array}{l}\text { TCM aqueous }(0.1 \text { and } 1 \mathrm{~g} / \mathrm{kg} \text {, } \\
\text { p. o.) }\end{array}$ & - & - & [79] \\
\hline $\begin{array}{l}\text { Gardenia jasminoides J. } \\
\text { Ellis (fruits) }\end{array}$ & $\begin{array}{l}\text { Acetic acid-in- } \\
\text { duced peritoneal } \\
\text { irritation and } \\
\text { streptozotocin- } \\
\text { induced diabetes }\end{array}$ & $\begin{array}{l}\text { Aqueous ( } 0.1 \text { and } 1 \mathrm{~g} / \mathrm{kg} \text {, } \\
\text { p. o.) }\end{array}$ & - & - & [79] \\
\hline $\begin{array}{l}\text { Coptis chinensis Franch. } \\
\text { (rhizome) }\end{array}$ & $\begin{array}{l}\text { Acetic acid-in- } \\
\text { duced peritoneal } \\
\text { irritation and } \\
\text { streptozotocin- } \\
\text { induced diabetes }\end{array}$ & Aqueous ( $1 \mathrm{~g} / \mathrm{kg}$, p. o.) & - & - & [79] \\
\hline $\begin{array}{l}\text { Phellodendron amurense } \\
\text { Rupr. (cortex) }\end{array}$ & $\begin{array}{l}\text { Acetic acid-in- } \\
\text { duced peritoneal } \\
\text { irritation and } \\
\text { streptozotocin- } \\
\text { induced diabetes }\end{array}$ & Aqueous ( $1 \mathrm{~g} / \mathrm{kg}$, p. o.) & - & - & [79] \\
\hline Zishi (Weikang pian) & $\begin{array}{l}{ }^{*} \text { Patients with } \\
\text { postprandial dis- } \\
\text { tress syndrome }\end{array}$ & $\begin{array}{l}\text { TCM rich in flavonoids } \\
\text { ( } 400 \text { mg, } 3 \text { times daily, p. o.) }\end{array}$ & - & - & {$[80]$} \\
\hline $\begin{array}{l}\text { Asdamarin (Ferula asa- } \\
\text { foetida H.Karst. and Sily- } \\
\text { bum marianum (L.) } \\
\text { Gaertn.) }\end{array}$ & $\begin{array}{l}\text { Rat model of gas- } \\
\text { tric motility }\end{array}$ & $\begin{array}{l}\text { Herbal formulation ( } 50 \text { and } \\
100 \mathrm{mg} / \mathrm{kg}, \text { p. o.) }\end{array}$ & - & - & {$[81]$} \\
\hline $\begin{array}{l}\text { Allium sativum L. (black } \\
\text { garlic) }\end{array}$ & $\begin{array}{l}\text { In vitro and in vivo } \\
\text { rat model of } \\
\text { gastrointestinal } \\
\text { motility }\end{array}$ & $\begin{array}{l}\mathrm{n} \text {-butanol and aqueous ( } 200 \\
\text { and } 400 \mathrm{mg} / \mathrm{kg}, \text { p. o.) }\end{array}$ & $\begin{array}{l}\text { Increased intesti- } \\
\text { nal 5-HT } 4 \text { content }\end{array}$ & - & [83] \\
\hline $\begin{array}{l}\text { Hippophae rhamnoides L. } \\
\text { (fruits) }\end{array}$ & $\begin{array}{l}\text { Mice model of } \\
\text { gastrointestinal } \\
\text { motility }\end{array}$ & $\begin{array}{l}\text { Methanol }(50-300 \mathrm{mg} / \mathrm{kg} \text {, } \\
\text { p. o.) }\end{array}$ & $\begin{array}{l}\text { Cholinergic } \\
\text { pathway }\end{array}$ & - & {$[85]$} \\
\hline $\begin{array}{l}\text { Salsola collina Pall. (over- } \\
\text { ground part) }\end{array}$ & $\begin{array}{l}\text { Rat model of } \\
\text { gastric motility }\end{array}$ & $\begin{array}{l}\text { Ethyl acetate }(40 \mathrm{mg} / \mathrm{kg}, \mathrm{p} . \text { o., } \\
\text { for } 7 \text { days) }\end{array}$ & $\begin{array}{l}\text { Increased plasma } \\
\text { ghrelin and gas- } \\
\text { trin; Elevated the } \\
\text { expression of } \\
\text { GSHR in the duo- } \\
\text { denum }\end{array}$ & - & {$[86]$} \\
\hline $\begin{array}{l}\text { Lepidium meyenii Walp. } \\
\text { (leaves) }\end{array}$ & $\begin{array}{l}\text { Mice model of } \\
\text { gastrointestinal } \\
\text { motility }\end{array}$ & $\begin{array}{l}\text { Powder }(0.54,1.08, \text { and } \\
2.16 \mathrm{~g} / \mathrm{kg} \text { for } 7 \text { days })\end{array}$ & - & $\begin{array}{l}\text { Benzyl isothio- } \\
\text { cyanate } \\
(0.18 \mathrm{mg} / \mathrm{kg})\end{array}$ & [87] \\
\hline
\end{tabular}

did not promote contractions in the small intestinal. The increase of $5-\mathrm{HT}_{4}$ receptor was evidenced in rats treated with $\mathrm{BA}$ or $\mathrm{AE}$, promoting the stimulation of gastrointestinal peristalsis, which enhanced gastrointestinal tract emptying. AE was incubated with gastric acid digestion and submitted to simulated hydrolysis. This process also significantly improved the intestinal contraction rate, indicating that black garlic compounds can be useful in treating gastrointestinal dysmotility linked to FD by the oral route.

Another promising natural resource for promoting prokinetic and gut excitatory effects is the fruit of Hippophae rhamnoides L. (Elaeagnaceae). Hanif et al. [85] showed that oral administration of the methanolic extract of $\mathrm{H}$. rhamnoides increased fecal production and charcoal meal transport. In a mechanistic approach, the 
extract's laxative and prokinetic effects were partially inhibited by atropine, evidencing participation of the cholinergic pathway. Although the study evidenced the laxative effects of the extract, the results reinforce earlier reports on the GE effects of $\mathrm{H}$. rhamnoides seed oil.

Extracts of Salsola collina Pall. (Amaranthaceae), widely distributed along the Bohai coast (China) and consumed as an edible plant by native residents, recently showed promising results. Wang et al. [86] tested different extracts from S. collina on the $\mathrm{GE}$ and small intestinal propulsion in healthy rats. The authors evidenced that the ethyl acetate extract (EAE) was the most effective fraction in promoting GE and intestinal propulsion in a dose-dependent manner. The mode of action was also investigated. The results showed that EAE increased plasma ghrelin and gastrin, elevated GSHR expression, and restrained VIPR2 in the duodenum. The authors of that study also used the organ bath technique to assess the in vitro effects of EAE on muscular tissue from the gastrointestinal tract. EAE promoted the contraction of normal gastric antrum strips, as well as relaxed strips induced by atropine. This result indicated that EAE could promote significant prokinetic activity via a mechanism that mainly involves ghrelin and gastrin modulation in the plasma and GSHR and VIPR2 expressions in the duodenum. Based on the in vitro results, it is also probable that EAE acts by activating muscarinic cholinergic receptors. Compared to other studies, Wang et al. [86] provide a robust pharmacological basis for using $S$. collina extract to treat gastrointestinal motility disorders, including FD by PDS.

Studies in the literature provide a rationale for using medicinal plants from the Andean regions, such as Lepidium meyenii Walp. (Brassicaceae), popularly named as "Maca". L. meyenii is used as food and for its medicinal value. jin et al. [87] quantified the protein, total sugar, vitamins, amino acids, and minerals and elucidated the active ingredients at 5 different growth stages of the aerial parts of "maca” (APM) and analyzed its prokinetic efficacy in vivo. Interestingly, in atropine-treated mice, $L$. meyenii powder accelerated GE and intestinal propulsion and serum motilin and gastrin. Motilin is an endogenous prokinetic hormone secreted by the gastrointestinal endocrine cells. This increase in serum levels of atropine-treated mice that received "Maca" powder revealed the participation of this hormone in the prokinetic effects of "Maca". The authors also showed that administration of benzyl isothiocyanate, a bioactive compound found in "Maca" powder, can promote gastrointestinal prokinetic efficacy.

An important criticism to be presented in this subchapter is the experimental design used in many studies. Several studies reviewed did not use at least 3 doses to evaluate the dose-response effect; therefore, adequate pharmacological comparison of potency and efficacy is impossible.

\section{Final Considerations}

Although herbal medicines are an ancient practice, it is only in recent decades that preclinical and clinical studies have focused on the effects of these preparations in treating dyspepsia. Several preclinical studies using critically validated models have been conducted with promising results. However, despite the positive outcomes described by preclinical studies, most of the effects of these preparations have yet to be investigated in depth to elucidate the mechanisms and compounds related to the effects found. The available data from controlled clinical studies are currently minimal. Indeed, some promising plant species are described in this article; however, clinical studies have not yet been developed to identify viable alternatives to conventional pharmacological treatments to control dyspepsia symptoms.

\section{Supporting Information}

Table 1S. Medicinal plants with studies reporting gastroprotective action are available as Supporting Information.

\section{Contributors' Statement}

Data collection: T. Boeing, P. de Souza, L. M. da Silva; design of the study: P. de Souza, L. M. da Silva, A. Gasparotto Junior; analysis and interpretation of the data: T. Boeing, P. de Souza, L. M. da Silva, Gasparotto Junior; design of the study: P. de Souza, L. M. da Silva, A. Gasparotto Junior; drafting the manuscript: T. Boeing; critical revision of the manuscript: P. de Souza, L. M. da Silva, A. Gasparotto Junior.

\section{Acknowledgements}

We are grateful to the Coordenação de Aperfeiçoamento de Pessoal de Nível Superior (CAPES) and Universidade do Vale do Itajaí (UNIVALI). To carry out this study, we also relied on the support of the Conselho Nacional de Desenvolvimento Científico e Tecnológico (CNPq) for providing a postdoctoral fellowship to Thaise Boeing.

Conflict of Interest

The authors declare that they have no conflict of interest.

\section{References}

[1] Talley NJ, Ford AC. Functional dyspepsia. N Engl J Med 2015; 373: $1853-$ 1863. doi:10.1056/NEJMra1501505

[2] Oustamanolakis P, Tack J. Dyspepsia: organic versus functional. J Clin Gastroenterol 2012; 46: 175-190. doi:10.1097/MCG. 0b013e318241b335

[3] Ford AC, Marwaha A, Sood R, Moayyedi P. Global prevalence of, and risk factors for, uninvestigated dyspepsia: a meta-analysis. Gut 2015; 64: 1049-1057. doi:10.1136/gutjnl-2014-307843

[4] Moayyedi P, Talley NJ, Fennerty MB, Vakil N. Can the clinical history distinguish between organic and functional dyspepsia? J Am Med Assoc 2006; 295: 1566-1576. doi:10.1001/jama.295.13.1566

[5] Hunt RH, Camilleri M, Crowe SE, El-Omar EM, Fox JG, Kuipers E], Malfertheiner P, McColl KE, Pritchard DM, Rugge M, Sonnenberg A, Sugano K, Tack J. The stomach in health and disease. Gut 2015; 64: 1650-1668. doi:10.1136/gutjnl-2014-307595

[6] Wauters L, Talley NJ, Walker MM, Tack J, Vanuytsel T. Novel concepts in the pathophysiology and treatment of functional dyspepsia. Gut 2019; 69: 591-600. doi:10.1136/gutjnl-2019-318536

[7] Madisch A, Andresen V, Enck P, Labenz J, Frieling T, Schemann M. The diagnosis and treatment of functional dyspepsia. Dtsch Arztebl Int 2018; 115: 222-232. doi:10.3238/arztebl.2018.0222

[8] Khonche A, Fallah Huseini H, Abdi H, Mohtashami R, Nabati F, Kianbakht S. Efficacy of Mentha pulegium extract in the treatment of functional dyspepsia: a randomized double-blind placebo-controlled clinical trial. | Ethnopharmacol 2017; 206: 267-273. doi:10.1016/j.jep.2017.05.026 
[9] Mohtashami R, Huseini HF, Heydari M, Amini M, Sadeqhi Z, Ghaznavi H, Mehrzadi S. Efficacy and safety of honey based formulation of Nigella sativa seed oil in functional dyspepsia: A double blind randomized controlled clinical trial. J Ethnopharmacol 2015; 175: 147-152. doi:10.1016/ j.jep.2015.09.022

[10] Ottillinger B, Storr M, Malfertheiner P, Allescher HD. STW 5 (Iberogast)a safe and effective standard in the treatment of functional gastrointestinal disorders. Wien Med Wochenschr 2013; 163: 65-72. doi:10.1007| s10354-012-0169-x

[11] Tijani SA, Olaleye SB, Farombi EO. Anti-ulcerogenic effect of the methanol extract of Chasmanthera dependens (Hochst) stem on male Wistar rats. J Basic Clin Physiol Pharmacol 2018; 29: 377-383. doi:10.1515/ jbcpp-2017-0152

[12] Koushki M, Farrokhi Yekta R, Amiri-Dashatan N, Dadpay M, Goshadrou F. Therapeutic effects of hydroalcoholic extract of Achillea wilhelmsii C. Koch on indomethacin-induced gastric ulcer in rats: a proteomic and metabolomic approach. BMC Complement Altern Med 2019; 19: 205. doi:10.1186/s12906-019-2623-4

[13] Athaydes BR, Alves GM, Assis ALEM, Gomes JVD, Rodrigues RP, Campagnaro BP, Nogueira BV, Silveira D, Kuster RM, Pereira TMC, Kitagawa RR, Gonçalves RCR. Avocado seeds (Persea americana Mill.) prevents indomethacin-induced gastric ulcer in mice. Food Res Int 2019; 119: 751760. doi:10.1016/j.foodres.2018.10.057

[14] Somensi LB, Boeing T, Cury BJ, Steimbach VMB, Niero R, de Souza LM, da Silva LM, de Andrade SF. Hydroalcoholic extract from bark of Persea major (Meisn.) L.E. Kopp (Lauraceae) exerts antiulcer effects in rodents by the strengthening of the gastric protective factors. J Ethnopharmacol 2017; 209: 294-304. doi:10.1016/j.jep.2017.08.007

[15] Selmi S, Rtibi K, Grami D, Sebai H, Marzouki L. Protective effects of orange (Citrus sinensis L.) peel aqueous extract and hesperidin on oxidative stress and peptic ulcer induced by alcohol in rat. Lipids Health Dis 2017; 16: 152. doi:10.1186/s12944-017-0546-y

[16] Paulrayer A, Adithan A, Lee JH, Moon KH, Kim DG, Im SY, Kang CW, Kim NS, Kim JH. Aronia melanocarpa (Black chokeberry) reduces ethanol-induced gastric damage via regulation of HSP-70, NF-kb, and MCP-1 signaling. Int J Mol Sci 2017; 18: 1195. doi:10.3390/ijms18061195

[17] Li X, Cao Y, Wong RK, Ho KY, Wilder-Smith CH. Visceral and somatic sensory function in functional dyspepsia. Neurogastroenterol Motil 2013; 25: 246-253. doi:10.1111/nmo.12044

[18] Park CH, Son HU, Yoo CY, Lee SH. Low molecular-weight gel fraction of Aloe vera exhibits gastroprotection by inducing matrix metalloproteinase- 9 inhibitory activity in alcohol-induced acute gastric lesion tissues. Pharm Biol 2017; 55: 2110-2115. doi:10.1080/13880209.2017. 1371770

[19] Lee CF, Fan CW, Chiang NN, Chang HC, Chen C, Huang YS, Wang HY, Lin WC, Chen FA. Protective effect of Corchorus capsularis L. leaves on ethanol-induced acute gastric mucosal lesion in rats. J Vet Med Sci 2019; 81: 1636-1642. doi:10.1292/jvms.19-0054

[20] Pereira Barbosa JA, Nascimento Santana MA, Campos Leite TC, de Oliveira TB, Barreto Mota FV, Gomes Alves Bastos IV, Corrêa AJC, de Amorim ELC, Cardoso Vieira JR, Sarmento Silva TM, Bandeira Delmiro Santana AL, do Nascimento MS, da Silva TG. Gastroprotective effect of ethyl acetate extract from Avicennia schaueriana Stapf \& Leechman and underlying mechanisms. Biomed Pharmacother 2019; 112: 108582. doi:10.1016/j.biopha.2019.01.043

[21] Hamid RA, Fong LM, Ting YL. Anti-arthritic and gastroprotective activities of Ardisia crispa root partially mediated via its antioxidant effect. J Complement Integr Med 2018; 15: 1-9. doi:10.1515/jcim-2017-0012

[22] Sousa GA, Oliveira IS, Silva-Freitas FV, Viana AFSC, Neto BPS, Cunha FVM, Gonçalves RLG, Lima Filho ACM, Amaral MPM, Oliveira RCM, Fernandes PD, Maciel JKS, da Silva TMS, Souza MFV, Oliveira FA. Gastroprotective effect of ethanol extracts of cladodes and roots of Pilosocereus gounellei (A. Weber ex K. Schum.) Bly. Ex Rowl (Cactaceae) on experimental ulcer models. J Ethnopharmacol 2018; 218: 100-108. doi:10.1016/j. jep.2018.02.009

[23] Byeon S, Oh J, Lim JS, Lee JS, Kim JS. Protective effects of Dioscorea batatas flesh and peel extracts against ethanol-induced gastric ulcer in mice. Nutrients 2018; 10: 1680. doi:10.3390/nu10111680

[24] Vidal CS, Oliveira Brito Pereira Bezerra Martins A, de Alencar Silva A, de Oliveira MRC, Ribeiro-Filho J, de Albuquerque TR, Coutinho HDM, da Silva Almeida JRG, Quintans LJ Junior, de Menezes IRA. Gastroprotective effect and mechanism of action of Croton rhamnifolioides essential oil in mice. Biomed Pharmacother 2017; 89: 47-55. doi:10.1016/j.biopha.2017.02.005

[25] Fahmy NM, Al-Sayed E, Michel HE, El-Shazly M, Singab ANB. Gastroprotective effects of Erythrina speciosa (Fabaceae) leaves cultivated in Egypt against ethanol-induced gastric ulcer in rats. J Ethnopharmacol 2020; 248: 112297. doi:10.1016/j.jep.2019.112297

[26] Nam HH, Choo BK. Geranium koreanum, a medicinal plant Geranii Herba, ameliorate the gastric mucosa injury in gastritis-induced mice. J Ethnopharmacol 2021; 252: 113041. doi:10.1016/j.jep.2020.113041

[27] Shou J, Kong X, Wang X, Tang Y, Wang C, Wang M, Zhang L, Liu Y, Fei C, Xue F, Li J, Zhang K. Tizoxanide inhibits inflammation in LPS-Activated RAW264.7 macrophages via the suppression of NF- $\kappa B$ and MAPK activation. Inflammation 2019; 42: 1336-1349. doi:10.1007/S10753-01900994-3

[28] Chen T, Mou Y, Tan J, Wei L, Qiao Y, Wei T, Xiang P, Peng S, Zhang Y, Huang Z, Ji $\mathrm{H}$. The protective effect of CDDO-Me on lipopolysaccharideinduced acute lung injury in mice. Int Immunopharmacol 2015; 25: $55-$ 64. doi:10.1016/J.INTIMP.2015.01.011

[29] Kong L, Smith W, Hao D. Overview of RAW264.7 for osteoclastogensis study: Phenotype and stimuli. J Cell Mol Med 2019; 23: 3077-3087. doi:10.1111/JCMM.14277

[30] Hartley JW, Evans LH, Green KY, Naghashfar Z, Macias AR, Zerfas PM, Ward JM. Expression of infectious murine leukemia viruses by RAW264.7 cells, a potential complication for studies with a widely used mouse macrophage cell line. Retrovirology 2008; 5: 1. doi:10.1186/ 1742-4690-5-1

[31] Akanda MR, Park BY. Involvement of MAPK/NF-KB signal transduction pathways: Camellia japonica mitigates inflammation and gastric ulcer. Biomed Pharmacother 2017; 95: 1139-1146. doi:10.1016/j.biopha. 2017.09.031

[32] Akanda MR, Kim IS, Ahn D, Tae HJ, Nam HH, Choo BK, Kim K, Park BY. Anti-inflammatory and gastroprotective roles of Rabdosia inflexa through downregulation of pro-inflammatory cytokines and MAPK/NF$\kappa B$ signaling pathways. Int J Mol Sci 2018; 19: 584. doi:10.3390/ ijms19020584

[33] Al-Quraishy S, Othman MS, Dkhil MA, Abdel Moneim AE. Olive (Olec europaea) leaf methanolic extract prevents $\mathrm{HCl} /$ ethanol-induced gastritis in rats by attenuating inflammation and augmenting antioxidant enzyme activities. Biomed Pharmacother 2017; 91: 338-349. doi:10.1016/ j.biopha.2017.04.069

[34] Yeo D, Hwang SJ, Kim WJ, Youn HJ, Lee HJ. The aqueous extract from Artemisia capillaris inhibits acute gastric mucosal injury by inhibition of ROS and NF-kB. Biomed Pharmacother 2018; 99: 681-687. doi:10.1016/j.biopha.2018.01.118

[35] de Araújo ERD, Guerra GCB, Araújo DFS, de Araújo AA, Fernandes JM, de Araújo Júnior RF, da Silva VC, de Carvalho TG, Ferreira LS, Zucolotto SM. Gastroprotective and antioxidant activity of Kalanchoe brasiliensis and Kalanchoe pinnata leaf juices against indomethacin and ethanol-induced gastric lesions in rats. Int J Mol Sci 2018; 19: 1265. doi:10.3390/ ijms19051265

[36] Enck P, Azpiroz F, Boeckxstaens G, Elsenbruch S, Feinle-Bisset C, Holtmann G, Lackner JM, Ronkainen J, Schemann M, Stengel A, Tack J, Zipfel S, Talley NJ. Functional dyspepsia. Nat Rev Dis Primers 2017; 3: 17081. doi:10.1038/nrdp.2017.81 
[37] Takeuchi K, Amagase K. Roles of cyclooxygenase, prostaglandin E2 and $E P$ receptors in mucosal protection and ulcer healing in the gastrointestinal tract. Curr Pharm Des 2018; 24: 2002-2011. doi:10.2174/ 1381612824666180629111227

[38] Chávez-Piña AE, Tapia-Álvarez GR, Reyes-Ramínrez A, Navarrete A. Carbenoxolone gastroprotective mechanism: participation of nitric oxide/ cGMP/K ATP pathway in ethanol-induced gastric injury in the rat. Fundam Clin Pharmacol 2011; 25: 717-722. doi:10.1111/j.14728206.2010.00897.x

[39] Abd El-Ghffar EA, Al-Sayed E, Shehata SM, Eldahshan OA, Efferth T. The protective role of Ocimum basilicum L. (Basil) against aspirin-induced gastric ulcer in mice: Impact on oxidative stress, inflammation, motor deficits and anxiety-like behavior. Food Funct 2018; 9: 4457-4468. doi:10.1039/c8fo00538a

[40] Kabeer KK, Ananthakrishnan N, Anand C, Balasundaram S. Prevalence of Helicobacter pylori infection and stress, anxiety or depression in functional dyspepsia and outcome after appropriate intervention. J Clin Diag Res 2017; 11: VC11-VC15. doi:10.7860/JCDR/2017/26745.10486

[41] Beber AP, de Souza P, Boeing T, Somensi LB, Mariano LNB, Cury B], Burci LM, da Silva CB, Simionatto E, de Andrade SF, da Silva LM. Constituents of leaves from Bauhinia curvula Benth. exert gastroprotective activity in rodents: role of quercitrin and kaempferol. Inflammopharmacology 2018; 26: 539-550. doi:10.1007/s10787-017-0313-8

[42] Alves Santana Cesário FR, Rodrigues de Albuquerque T, Fernandes da Silva BA, Mendes de Lacerda G, Rodrigues LB, Brito Pereira Bezerra Martins AO, Quintans-Júnior LJ, Guedes da Silva Almeida JR, Vale ML, Melo Coutinho HD, Alencar de Menezes IR. Evaluation of the antioxidant and gastroprotective activity and HPLC analysis of the hydroalcoholic extract of Tocoyena formosa leaves (Cham. \& Schlecht) K. Schum. Food Chem Toxicol 2018; 112: 355-362. doi:10.1016/j.fct.2017.12.058

[43] da Rosa RL, de Almeida CL, Somensi LB, Boeing T, Mariano LNB, de Medeiros Amorim Krueger C, de Souza P, Filho VC, da Silva LM, de Andrade SF. Chrysophyllum cainito (apple-star): a fruit with gastroprotective activity in experimental ulcer models. Inflammopharmacology 2019; 27: 985-996. doi:10.1007/s10787-017-0427-z

[44] Arunachalam K, Damazo AS, Pavan E, Oliveira DM, Figueiredo FF, Machado MTM, Balogun SO, Soares IM, Barbosa RDS, Alvim TDC, Ascêncio SD, Martins DTO. Cochlospermum regium (Mart. ex Schrank) Pilg.: Evaluation of chemical profile, gastroprotective activity and mechanism of action of hydroethanolic extract of its xylopodium in acute and chronic experimental models. J Ethnopharmacol 2019; 233: 101-114. doi:10.1016/j.jep.2019.01.002

[45] de Lacerda Neto LJ, Ramos AG, Santos Sales V, de Souza SD, Dos Santos AT, de Oliveira LR, Kerntopf MR, de Albuquerque TR, Coutinho HD, Quintans-Júnior LJ, Wanderley AG, de Menezes IR. Gastroprotective and ulcer healing effects of hydroethanolic extract of leaves of Caryocar coriaceum: mechanisms involved in the gastroprotective activity. Chem Biol Interactions 2017; 261: 56-62. doi:10.1016/j.cbi.2016.11.020

[46] He H, Feng M, Xu H, Li X, He Y, Qin H, Zhang Y, Tang H, Zou K. Total triterpenoids from the fruits of Chaenomeles speciosa exerted gastroprotective activities on indomethacin-induced gastric damage via modulating microRNA-423-5p-mediated TFF/NAG-1 and apoptotic pathways. Food Funct 2020; 11: 662-679. doi:10.1039/c9fo02322d

[47] Zhang Y, Xu H, He H, Li X, Feng M, He Y, Jiang W, Wang J, Xu D, Zou K. Total triterpenes from the fruits of Chaenomeles speciosa (Sweet) Nakai protects against indomethacin-induced gastric mucosal injury: involvement of TFF1-mediated EGF/EGFR and apoptotic pathways. J Pharm Pharmacol 2020; 72: 409-423. doi:10.1111/jphp.13207

[48] Lebda MA, El-Far AH, Noreldin AE, Elewa YHA, Al Jaouni SK, Mousa SA. Protective effects of Miswak (Salvadora persica) against experimentally induced gastric ulcers in rats. Oxid Med Cell Longev 2018; 2018: 6703296. doi:10.1155/2018/6703296

[49] Karaboğa I, Ovalı MA, Yılmaz A, Alpaslan M. Gastroprotective effect of apricot kernel oil in ethanol-induced gastric mucosal injury in rats. Bio- tech Histochem 2018; 93: 601-607. doi:10.1080/10520295.2018. 1511064

[50] Omar H, Nordin N, Hassandarvish P, Hajrezaie M, Azizan AHS, Fadaeinasab M, Abdul Majid N, Abdulla MA, Mohd Hashim N, Mohd Ali $\mathrm{H}$. Methanol leaf extract of Actinodaphne sesquipedalis (Lauraceae) enhances gastric defense against ethanol-induced ulcer in rats. Drug Des Devel Ther 2017; 11: 1353-1365. doi:10.2147/DDDT.S120564

[51] Al-Wajeeh NS, Hajerezaie M, Noor SM, Halabi MF, Al-Henhena N, Azizan AH, Kamran S, Hassandarvish P, Shwter AN, Karimian H, Ali HM, Abdulla MA. The gastro protective effects of Cibotium barometz hair on ethanolinduced gastric ulcer in Sprague-Dawley rats. BMC Vet Res 2017; 13: 27. doi:10.1186/s12917-017-0949-z

[52] Al-Wajeeh NS, Hajrezaie M, Al-Henhena N, Kamran S, Bagheri E, Zahedifard M, Saremi K, Noor SM, Ali HM, Abdulla MA. The antiulcer effect of Cibotium barometz leaves in rats with experimentally induced acute gastric ulcer. Drug Des Devel Ther 2017; 11: 995-1009. doi:10.2147/DDDT.S107018

[53] He H, Li X, Yu H, Zhu S, He Y, Komatsu K, Guo D, Li X, Wang J, Luo H, Xu $D$, Zou K. Gastroprotective effect of araloside A on ethanol- and aspirininduced gastric ulcer in mice: involvement of $\mathrm{H}+/ \mathrm{K}+$-ATPase and mitochondrial-mediated signaling pathway. J Nat Med 2019; 73: 339-352. doi:10.1007/s11418-018-1256-0

[54] Shin JM, Vagin O, Munson K, Kidd M, Modlin IM, Sachs G. Molecular mechanisms in therapy of acid-related diseases. Cell Mol Life Sci 2008; 65: 264-281. doi:10.1007/s00018-007-7249-x

[55] Ishikawa T, Donatini Rdos S, Diaz IE, Yoshida M, Bacchi EM, Kato ET. Evaluation of gastroprotective activity of Plinia edulis (Vell.) Sobral (Myrtaceae) leaves in rats. J Ethnopharmacol 2008; 118: 527-529. doi:10.1016/j.jep.2008.05.007

[56] da Rosa RL, Nesello LÂN, Mariano LNB, Somensi LB, Campos A, Pinheiro AM, Costa S, Rial M, Tozzo M, Cechinel-Filho V, de Andrade SF, da Silva LM. Gastroprotective activity of the methanol extract from peels of Plinia edulis (Vell.) Sobral fruits and its isolated triterpenes: maslinic and ursolic acids. Naunyn Schmiedebergs Arch Pharmacol 2018; 391: 95-101. doi:10.1007/s00210-017-1442-8

[57] Jackson MA, Goodrich JK, Maxan ME, Freedberg DE, Abrams JA, Poole AC, Sutter JL, Welter D, Ley RE, Bell JT, Spector TD, Steves CJ. Proton pump inhibitors alter the composition of the gut microbiota. Gut 2016; 65: 749-756. doi:10.1136/gutjnl-2015-310861

[58] Chellappan DR, Purushothaman AK, Brindha P. Gastroprotective potential of hydroalcoholic extract of Pattanga (Caesalpinia sappan Linn.). J Ethnopharmacol 2017; 197: 294-305. doi:10.1016/j.jep.2016.07.081

[59] Hatware KV, Sharma S, Patil K, Shete M, Karri S, Gupta G. Evidence for gastroprotective, anti-inflammatory and antioxidant potential of methanolic extract of Cordia dichotoma leaves on indomethacin and stress induced gastric lesions in Wistar rats. Biomed Pharmacother 2018; 103 : 317-325. doi:10.1016/j.biopha.2018.04.007

[60] Piessevaux H, De Winter B, Louis E, Muls V, De Looze D, Pelckmans P, Deltenre M, Urbain D, Tack J. Dyspeptic symptoms in the general population: a factor and cluster analysis of symptom groupings. Neurogastroenterol Motil 2009; 21: 378-388. doi:10.1111/j.13652982.2009.01262x

[61] Ismail Suhaimy NW, Noor Azmi AK, Mohtarrudin N, Omar MH, Tohid SF, Cheema MS, Teh LK, Salleh MZ, Zakaria ZA. Semipurified ethyl acetate partition of methanolic extract of Melastoma malabathricum leaves exerts gastroprotective activity partly via its antioxidant-antisecretoryanti-inflammatory action and synergistic action of several flavonoidbased compounds. Oxid Med Cell Longev 2017; 2017: 6542631. doi:10.1155/2017/6542631

[62] Palle S, Kanakalatha A, Kavitha CN. Gastroprotective and antiulcer effects of Celastrus paniculatus seed oil against several gastric ulcer models in rats. J Diet Suppl 2018; 15: 373-385. doi:10.1080/19390211.2017. 1349231 
[63] Tack J, Carbone F. Functional dyspepsia and gastroparesis. Curr Opin Gastroenterol 2017; 33: 446-454. doi:10.1097/MOG.000000000 0000393

[64] Almeida GVB, Arunachalam K, Balogun SO, Pavan E, Ascêncio SD, Soares IM, Zanatta AC, Vilegas W, Macho A, Oliveira Martins DT. Chemical characterization and evaluation of gastric antiulcer properties of the hydroethanolic extract of the stem bark of Virola elongata (Benth.) Warb. J Ethnopharmacol 2019; 231: 113-124. doi:10.1016/j.jep.2018.11.011

[65] Thorell K, Yahara K, Berthenet E, Lawson DJ, Mikhail ], Kato I, Mendez A, Rizzato C, Bravo MM, Suzuki R, Yamaoka Y, Torres J, Sheppard SK, Falush D. Rapid evolution of distinct Helicobacter pylori subpopulations in the Americas. PLoS Genet 2017; 13: 1006546. doi:10.1371/journal. pgen.1006546

[66] Feng L, Wen MY, Zhu Y], Men RT, Yang L. Sequential therapy or standard triple therapy for Helicobacter pylori infection: an updated systematic review. Am J Ther 2016; 23: e880-e893. doi:10.1097/MJT. 0000000000000191

[67] Szajewska H, Horvath A, Kołodziej M. Systematic review with meta-analysis: Saccharomyces boulardii supplementation and eradication of Helicobacter pylori infection. Aliment Pharmacol Ther 2015; 41: 1237-1245. doi:10.1111/apt.13214

[68] Park JU, Cho JS, Kim JS, Kim HK, Jo YH, Rahman MAA, Lee YI. Synergistic Effect of Rubus crataegifolius and Ulmus macrocarpa Against Helicobacter pylori Clinical Isolates and Gastritis. Front Pharmacol 2020; 11: 4. doi:10.3389/fphar.2020.00004

[69] Ibrahim NH, Awaad AS, Alnafisah RA, Alqasoumi SI, El-Meligy RM, Mahmoud AZ. In - vitro activity of Desmostachya bipinnata (L.) Stapf successive extracts against Helicobacter pylori clinical isolates. Saudi Pharm J 2018; 26: 535-540. doi:10.1016/j.jsps.2018.02.002

[70] Park HS, Wijerathne CUB, Jeong HY, Seo CS, Ha H, Kwun H]. Gastroprotective effects of Hwanglyeonhaedok-tang against Helicobacter pylori-induced gastric cell injury. J Ethnopharmacol 2018; 216: 239-250. doi:10.1016/j.jep.2018.01.025

[71] Lee HA, Hong S, Yoo JH, Chung Y, Kim O. Anti-Helicobacter pylori activity and inhibition of gastritis by Allium hookeri extract. Lab Anim Res 2018; 34: 75-79. doi:10.5625/lar.2018.34.2.75

[72] Prazeres LDKT, Aragão TP, Brito SA, Almeida CLF, Silva AD, de Paula MMF, Farias JS, Vieira LD, Damasceno BPGL, Rolim LA, Veras BO, Rocha IG, Silva Neto JC, Bittencourt MLF, Gonçalves RCR, Kitagawa RR, Wanderley AG. Antioxidant and antiulcerogenic activity of the dry extract of pods of $\mathrm{Li}$ bidibia ferrea Mart. ex Tul. (Fabaceae). Oxid Med Cell Longev 2019; 2019: 1983137. doi:10.1155/2019/1983137

[73] Spósito L, Oda FB, Vieira JH, Carvalho FA, Dos Santos Ramos MA, de Castro RC, Crevelin E], Crotti AEM, Santos AG, da Silva PB, Chorilli M, Bauab TM. In vitro and in vivo anti-Helicobacter pylori activity of Casearia sylvestris leaf derivatives. J Ethnopharmacol 2019; 233: 1-12. doi:10.1016/j. jep.2018.12.032

[74] Aguiar BAA, Bueno FG, Panizzon G, Silva DBD, Athaydes BR, Gonçalves RCR, Kitagawa RR, Marques LLM, Paula MN, Antonelli-Ushirobira TM, Medeiros DC, Mello JCP. Chemical analysis of the semipurified extract of Paullinia cupana and evaluation of in vitro inhibitory effects against Helicobacter pylori. Nat Prod Res 2020; 34: 2332-2335. doi:10.1080/ 14786419.2018.1533825
[75] Kouitcheu Mabeku LB, Eyoum Bille B, Tchouangueu TF, Nguepi E, Leundji $\mathrm{H}$. Treatment of Helicobacter pylori infected mice with Bryophyllum pinnatum, a medicinal plant with antioxidant and antimicrobial properties, reduces bacterial load. Pharm Biol 2017; 55: 603-610. doi:10.1080/ 13880209.2016.1266668

[76] Wang Y, Wang SL, Zhang JY, Song XN, Zhang ZY, Li JF, Li S. Anti-ulcer and anti-Helicobacter pylori potentials of the ethyl acetate fraction of Physalis alkekengi L. var. franchetii (Solanaceae) in rodent. J Ethnopharmacol 2018; 211: 197-206. doi:10.1016/j.jep.2017.09.004

[77] Sreeja PS, Arunachalam K, Saikumar S, Kasipandi M, Dhivya S, Murugan R, Parimelazhagan T. Gastroprotective effect and mode of action of methanol extract of Sphenodesme involucrata var. paniculata (C.B. Clarke) Munir (Lamiaceae) leaves on experimental gastric ulcer models. Biomed Pharmacother 2018; 97: 1109-1118. doi:10.1016/j.biopha. 2017.11.030

[78] Camilleri M, Chedid V, Ford AC, Haruma K, Horowitz M, Jones KL, Low PA Park SY, Parkman HP, Stanghellini V. Gastroparesis. Nat Rev Dis Primers 2018; 4: 41. doi:10.1038/s41572-018-0038-z

[79] Kim H, Kim I, Lee MC, Kim HJ, Lee GS, Kim H, Kim BJ. Effects of Hwangryunhaedok-tang on gastrointestinal motility function in mice. World J Gastroenterol 2017; 23: 2705-2715. doi:10.3748/wjg.v23.i15.2705

[80] Yan L, Yu L, Zhao L, Wang D, Qin D, Fan H, Cheng L, Qiu M, Chen X, Zhou L, Qiu J, Yao J, Wang W, Qiu X. Efficacy of Weikang Pian in patients with functional dyspepsia: a double-blind, randomized, placebo-controlled clinical trial. Evid Based Complement Alternat Med 2019; 2019: 4827046. doi:10.1155/2019/4827046

[81] Illuri R, Venkataramana SH, Daguet D, Kodimule S. Sub-acute and acute toxicity of Ferula asafoetida and Silybum marianum formulation and effect of the formulation on delaying gastric emptying. BMC Complement Alternat Med 2019; 19: 1-11. doi:10.1186/s12906-019-2576-7

[82] Zhong C, Zhan P, Tian H, Wang P, Lei F. Antiulcer activity of the three different extracts of Ferula lehmannii Boiss leaf in rats. Pak J Pharm Sci 2019; 32: 2625-2632

[83] Chen YA, Tsai JC, Cheng KC, Liu KF, Chang CK, Hsieh CW. Extracts of black garlic exhibits gastrointestinal motility effect. Food Res Int 2018; 107: 102-109. doi:10.1016/j.foodres.2018.02.003

[84] Avula PR, Asdaq SM, Asad M. Effect of aged garlic extract and s-allyl cysteine and their interaction with atenolol during isoproterenol induced myocardial toxicity in rats. Indian J Pharmacol 2014; 46: 94-99. doi:10.4103/0253-7613.125185

[85] Hanif M, Mehmood MH, Ishrat G, Abdullah A, Sohail S, Ahmed M, Gilani AH. Evaluation of prokinetic and laxative effects of Hippophae rhamnoides in rodents. Pak J Pharm Sci 2019; 32: 2527-2533

[86] Wang S, Yan M, Guo Y, Sun R, Jin H, Gong Y. In vivo and in vitro effects of Salsola collina on gastrointestinal motility in rats. Iran J Basic Med Sci 2020; 23: 383-389. doi:10.22038/IJBMS.2019.40613.9605

[87] Jin W, Chen X, Huo Q, Cui Y, Yu Z, Yu L. Aerial parts of maca (Lepidium meyenii Walp.) as functional vegetables with gastrointestinal prokinetic efficacy in vivo. Food Funct 2018; 9: 3456-3464. doi:10.1039/ c8fo00405f 